\title{
Giant-Cell Arteritis: Immunopathogenic Mechanisms Involved in Vascular Inflammation and Remodeling
}

Ester Planas-Rigol, Marc Corbera-Bellalta, Georgina Espígol-Frigolé, Nekane Terrades-García, Marco A Alba, Sergio Prieto-González, Jose HernándezRodríguez, Ester Lozano and Maria C Cid ${ }^{*}$

Department of Autoimmune Diseases, Hospital Clínic, University of Barcelona, Spain

*Corresponding author: Maria C Cid, Department of Autoimmune Diseases, Hospital Clínic, University of Barcelona, Spain, Tel: +34 93 2279365; E-mail: mccid@clinic.ub.es

Received date: December 21, 2015; Accepted date: January 18, 2016; Published date: January 24, 2016

Copyright: (C) 2015 Rigol EP, et al. This is an open-access article distributed under the terms of the Creative Commons Attribution License, which permits unrestricted use, distribution, and reproduction in any medium, provided the original author and source are credited.

\begin{abstract}
Giant-cell arteritis (GCA) is a large-vessel granulomatous vasculitis in which aging, gender and genetics likely play a significant role. The association with polymorphisms in the major histocompatibility complex suggests that GCA may be an antigen-driven disease. Immunopathology studies performed with temporal artery biopsies from patients with GCA have generated relevant clues regarding to pathogenesis by indicating participation of Th1 and Th17-mediated pathways, a prominent role for macrophages in tissue injury, and the relevance of vascular response to inflammation. Vascular wall elements, especially endothelial cells and vascular smooth muscle cells are not passive bystanders. Through expression of chemokines and adhesion molecules vascular cells contribute to the continuous recruitment of inflammatory cells that are able to enter the artery wall through newly formed neovessels. Inflammatory cell products, as well as vascular injury, trigger a vascular remodelling process. This eventually leads to the development of intimal hyperplasia and vascular lumen obliteration, source of ischemic complications.
\end{abstract}

\section{Key words}

Vasculitis; Giant-cell arteritis; Genetic polymorphisms; Inflammation; Cytokines; Growth factors; Angiogenesis; Vascular remodelling.

\section{Introduction}

Giant-cell arteritis (GCA) is a granulomatous vasculitis affecting large and medium-sized vessels with a special tropism for the carotid and vertebral arteries [1]. Involvement of the superficial temporal artery is very frequent and performance of temporal artery biopsies is a common diagnostic procedure which facilitates histopathological confirmation of GCA (Figure 1) [2]. Temporal artery biopsies are also a source of valuable tissue not only for diagnostic purposes but also for immunopathology studies which have provided important pathogenetic clues. In fact, the current pathogenesis model is essentially based on the demonstration of particular cell types and subsets in involved tissue or peripheral blood, the expression of activation and differentiation markers by these cells and the production of certain inflammatory molecules in lesions. The role of infiltrating cells and their products is assumed from their known biologic functions and from correlation with relevant histopathological features, clinical phenotypes or disease outcomes [3,4]. However, the pathogenesis of GCA is incompletely understood due to the limited availability of functional studies where the participation of specific pathways can be mechanistically proved.
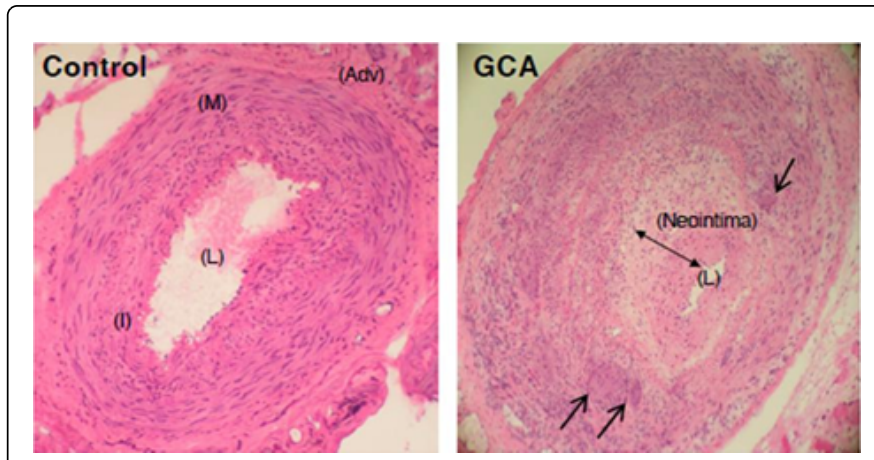

Figure 1: Normal temporal artery biopsy (left) as opposed to a temporal artery biopsy from a patient with giant-cell arteritis (right) disclosing typical transmural mononuclear cell infiltration, internal elastic lamina breakdown and intimal hyperplasia. Double head arrow remarks the thickened intima and single head arrows indicate the presence of giant-cells. Haematoxylin-eosin staining. L: lumen; I: intima; M: media; Adv: adventitia.

\section{Predisposing background}

Epidemiology surveys indicate that genetic substrate, senescence and gender contribute to GCA pathogenesis [5]. GCA selectively targets aged individuals and predominates in women. However, the role of aging and gender remains virtually unexplored in GCA. Both senescence of the immune system and the arterial tree may be relevant. Recently, senescent $\mathrm{T}$ cells $\left(\mathrm{CD}^{4+} \mathrm{CD}^{28-}\right)$ have been identified in GCAinvolved temporal arteries and are found in increased numbers in peripheral blood from patients with several chronic inflammatory diseases, including GCA [6]. Some of these cells express NKG2D 
receptors and their ligation induces expression of IFN $\gamma$ and TNFa, which are relevant cytokines in GCA. Therefore, senescent $\mathrm{T}$ cells may have pro-inflammatory responses, facilitating subsequent inflammatory cascades.

GCA largely predominates in Caucasians, particularly in those from Northern European regions or ancestry. This observation, along with the occasionally reported familiar clustering, supports genetic predisposition to develop GCA $[7,8]$. Polymorphisms in a variety of genes encoding for molecules participating in immune, inflammatory, and vascular responses (i.e., class II major histocompatibility complex (MHC), PTPN22, NOS2, VEGF) are associated with increased GCA risk [8-10].

GCA has been consistently found to be associated with the MHC particularly with class II HLA-DRB1 ${ }^{\star} 04$ alleles (generally DRB ${ }^{\star} 0401$, but also $\mathrm{DRB}^{\star}{ }^{\star 0404)}[8,11]$. A large-scale genetic survey based on international multi-centre collaboration has recently confirmed that the strongest association identified occurs with variants in the class II MHC and that the resulting risk amino acids are located in the antigen-binding cavity of the HLA molecule [12]. This finding reinforces the role of adaptive immunity and supports the concept that GCA may be an antigen-driven disease.

\section{Initial events: $\mathbf{T}$ cell activation and functional differentiation}

The nature of the triggering agent or agents has not been consistently identified. Although various microorganisms or viruses have been proposed as causal agents, no definitive causal relationship with a particular microorganism or virus has been demonstrated $[13,14]$. A variety of microbe and viral sequences have been detected in temporal arteries but none has consistently been associated with GCA [15]. These sequences might contribute to activate pathogen sensing receptors since both innate and adaptive immune mechanisms appear to contribute to GCA [4]. Dendritic cells have been detected in normal or early inflamed large and medium-sized arteries [16-19] and can be activated through toll-like receptors (TLR) to produce chemokines that attract and retain additional dendritic cells $[17,18,20]$. Activated dendritic cells are able to process and present antigens and express costimulatory molecules (CD83 and CD86) for T -cell activation [17,18]. The participation of antigen-specific adaptive immune responses is supported by the demonstration of oligoclonal $\mathrm{T}$ cell expansion in lesions [21]. The role of the immunological synapsis and accessory molecules in $\mathrm{T}$-cell activation is supported by interesting observations. On one hand there are several case reports of patients with metastatic melanoma who have developed GCA shortly after receiving ipilimumab (anti -CTLA-4), a form of immunostimulatory therapy favouring CD28-mediated $\mathrm{T}$ cell stimulation by neutralizing the inhibitory molecule CTLA-4 [22,23]. Moreover, preliminary results indicate that abatacept (recombinant chimeric Ig-CTLA-4) may be useful for sustaining remission in patients with GCA [24]. After antigen recognition, both Th1 and Th17 differentiation pathways seem to be crucial to the pathogenesis of GCA. IFN $\gamma$ is markedly and selectively expressed in GCA-involved arteries [25,26] and its functional impact is supported by the expression of many interferoninduced products in lesions including class II MHC antigens [16], endothelial adhesion molecules [27], inducible nitric oxide synthase [28] and chemokines $[26,29,30]$. One of the most relevant functions of IFN $\gamma$ is macrophage activation, granuloma formation and differentiation into giant-cells, all characteristically found in GCA lesions (Figures 1 and 2). Activated macrophages subsequently orchestrate a variety of inflammation amplifying cascades. These are seminal to the development of full-blown transmural inflammatory infiltrates, vascular wall injury and remodelling, which configure the pathologic substrate of the clinical symptoms and complications of GCA $[2-4,16,26,28]$. In recent years it has become apparent that Th17mediated mechanisms also contribute to GCA [31-33]. CD161 positive CD4T lymphocytes which are precursors of Th1 and Th17 functional subsets can be identified in inflammatory infiltrates [34]. Cytokines promoting Th17 differentiation such as IL-1, IL-21, TGFa, and IL-6 are produced in GCA $[25,28,35,36]$. Consequently, IL-17A is remarkably expressed in lesions [32]. IL-17A is a highly pro-inflammatory cytokine with pleiotropic effects on a variety of cells including macrophages, neutrophils, endothelial cells and fibroblasts and actively contributes to inflammatory cascades [37]. Both Th1 and Th17 lymphocyte numbers are increased in peripheral blood from patients with GCA where a Th1-Th17 double positive cell population can be also detected [34,35,38]. IL-17A expression rapidly and remarkably decreases with glucocorticoid treatment suggesting that IL-17A suppression may contribute to the dramatic symptomatic improvement that most patients with GCA experience with high dose glucocorticoids [32]. Patients with prominent Th17 response seem to respond better to glucocorticoids and experience less relapses [32]. Consistent with these findings, genes related to T-cell activation and Th1 and Th17 differentiation are hypomethylated in GCA lesions [39].

Regulatory $\mathrm{T}$ cells, limiting immune activation and the accompanying inflammatory response are also present in vascular lesions and are decreased in peripheral blood from patients with GCA $[32,34]$. According to the well-recognized plasticity among $\mathrm{T}$ cell subsets, in a strong inflammatory microenvironment, such as GCA lesions, regulatory $\mathrm{T}$ cells may not be suppressive and may produce IL-17A [32].

\section{Other cell types contributing to GCA pathogenesis}

The role of B cells in GCA has been neglected for years. However, B lymphocytes are present in vascular inflammatory lesions [16,40,41] and may have an even more important role in lymphoid organs. Decreased concentrations of circulating B lymphocytes have been observed in patients with active GCA, which recover with glucocorticoid treatment [40]. Although GCA has been primarily considered a T-cell mediated disease, B-lymphocytes are crucial to Tcell activation. Consistent with the potential participation of B cells, a few reports refer improvement of relapsing patients with B-cell depletion therapy with rituximab $[42,43]$. A variety of auto-antibodies have been detected in sera from patients with GCA. These include anti-ferritin antibodies, anti-endothelial or anti-vascular smooth muscle cell antibodies recognizing different antigens (i.e., vinculin, annexin $\mathrm{V}$, among others) [44,45]. However, disease specificity, and the consequent diagnostic performance of these antibodies has not been widely validated. More recently, circulating auto-antibodies against 14-3-3, a pleiotropic protein in nucleated cells, have been detected in patients with aortic aneurysm due to large-vessel vasculitis [46]. It is likely that many of these antibodies are generated as a consequence of inflammation and tissue injury rather than having a primary pathogenic role. The biologic significance and diagnostic performance of these auto-antibodies needs further investigation.

Neutrophils are scarce in GCA transmural inflammatory infiltrates but are clearly present in small vessels surrounding the temporal artery and in early inflammatory infiltrates surrounding vasa vasorum $[47,48]$. Recently, changes in the phenotype of circulating neutrophils have been detected in patients with GCA. In patients treated with high 
Citation: Planas-Rigol E, Corbera-Bellalta M, Espígol-Frigolé G, Terrades-Garcia N, Alba MA, et al. (2016) Giant-Cell Arteritis: Immunopathogenic Mechanisms Involved in Vascular Inflammation and Remodeling. J Vasc 1: 103. doi:10.4172/2471-9544.100103

Page 3 of 7

dose glucocorticoids, neutrophils have lower membrane expression of integrin CD11b, are less adhesive to endothelial cells and are able to suppress $\mathrm{T}$ cell proliferation. These abnormalities revert when glucocorticoids are tapered along with the rebound in elevated serum concentrations of IL-8, IL-6 and IL-17 which are able to induce a proinflammatory phenotype in neutrophils in vitro [49].

\section{Amplification cascades}

Following these initiating events, magnifying loops are crucial in the development and progression of transmural inflammatory infiltrates in GCA. Pro-inflammatory macrophages produce cytokines with prominent local and systemic effects and with a strong impact in disease manifestations and outcome. TNF $\alpha$, IL-1 $\beta$, IL-6, and IL-33 are expressed in GCA lesions and their expression correlates with the intensity of the systemic inflammatory response, characteristic of GCA $[35,50]$. Moreover, tissue expression of TNF $\alpha$ and circulating TNFa and IL-6 correlate with relapses and disease persistence [35,51]. Chemokines, endothelial adhesion molecules and colony-stimulating factors are induced or increased in lesions and reinforce inflammatory loops by continuously recruiting and expanding the half-life of additional inflammatory cells [25-27,29]. Angiogenic factors such as VEGF, FGF-2, and PDGFs, among others, are expressed in vascular lesions of GCA and promote new vessel formation [3,52,53]. Acute phase proteins, typically increased in GCA patients, may also be angiogenic [54,55]. Neovessels express endothelial adhesion molecules providing new vascular entries for infiltrating leukocytes and may sustain the active metabolic demands of the inflammatory process $[3,27]$ (Figure 3). The role of neovessels in recruiting phagocytes is supported by the strong expression of MRP8 and MRP12 in surrounding leukocytes. MRP8 is expressed by circulating and freshly recruited phagocytes but expression is lost in tissue macrophages [48]. In addition to favouring the progression of inflammation, angiogenesis may have a protective role by compensating for ischemia at distal sites, and a strong angiogenic response in lesions is associated with lower frequency of neuro-ophthalmic ischemic complications [56,57].
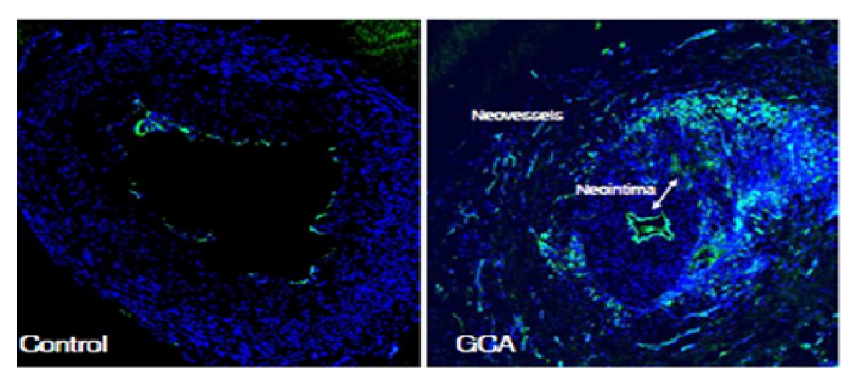

Figure 3: Extensive neovascularization in the artery wall occurs in giant-cell arteritis. In a normal temporal artery (left) only the luminal endothelium is apparent whereas in a giant-cell arteritis involved artery, multitude of neovessels can be detected by endothelial staining (green). Immunofluorescence staining of endothelial cells using a FITC-conjugated mouse anti- human CD31 monoclonal antibody (ImmunoTools). Nuclei are stained with Hoechst (blue).

\section{Arterial damage}

Activated macrophages produce reactive oxygen species which contribute to oxidative damage and vessel wall injury [28]. Proteases may also have an important destructive role. Matrix metalloproteases MMP-9 and MMP-2 have elastinolytic activity and are up-regulated in GCA lesions whereas their natural inhibitors TIMP- 1 and TIMP-2 are down-regulated yielding an increase in proteolytic balance $[28,58]$. Increased MMP9/MMP2 proteolytic activity has been demonstrated in lesions and likely contributes to disruption of elastic fibres and abnormal vascular remodelling [58,59] (Figure 2). Disruption of elastic fibres may favour aortic dilatation, an increasingly recognized delayed complication in patients with GCA [59-62].
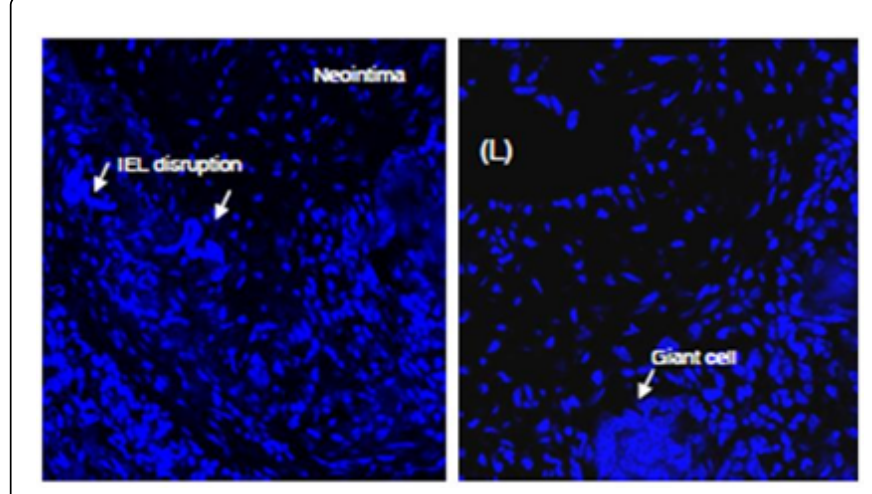

Figure 2: Internal elastic lamina (IEL) disruption favours the progression of inflammatory infiltrates (left). Multinucleated giantcells, the hallmark of giant-cell arteritis (arrows) are frequently abundant (right). Nuclear fluorescent staining (Hoechst) examined under confocal microscopy (blue).

Currently, the treatment of GCA mainly relies on glucocorticoids which elicit a rapid relief of symptoms but fail to induce sustained remission in $60-70 \%$ of patients [63]. Moreover, glucocorticoids are unable to avoid aortic dilatation in $22-30 \%$ of affected individuals $[59,60]$. Understanding the pathogenic mechanisms leading to GCA may foster the identification of better therapeutic agents. The association between increased expression of TNFa and persistent disease activity observed in various studies $[35,51]$ provided support to the performance of clinical trials blocking TNF with infliximab, etanercept or adalimumab which, unfortunately, have proven to be insufficient to abrogate disease activity and maintain remission, presumably due to redundancy in concomitantly activated inflammatory pathways [64-66]. IL-6 is a multifunctional cytokine involved not only in inducing the acute phase response and its systemic manifestations but also in inducing Th17 differentiation and promoting B cell functions. Currently, blocking the IL-6 receptor with tocilizumab is being tested in large international multicenter trials [67-68]. Recently communicated results indicate that tocilizimab may be more effective than placebo in reducing relapses in patients with short exposure to glucocorticoids [68]. IL-1 $\beta$ and IL-17A are additional potential targets. As mentioned, both are potent proinflammatory cytokines profusely expressed in GCA lesions. Moreover, IL-1 receptor antagonist deficiency results in large vessel arteritis in a mouse model [69]. Mice deficient in IRF-4 binding protein leading to increased expression of IL-21 and IL-17A develop large-vessel vasculitis as well [70]. Proof of concept pilot studies testing IL- $1 \alpha$ and IL-17 antagonism are ongoing (www.clinicaltrials.gov). As mentioned, 
Citation: Planas-Rigol E, Corbera-Bellalta M, Espígol-Frigolé G, Terrades-Garcia N, Alba MA, et al. (2016) Giant-Cell Arteritis: Immunopathogenic Mechanisms Involved in Vascular Inflammation and Remodeling. J Vasc 1: 103. doi:10.4172/2471-9544.100103

Page 4 of 7

interfering with CD28-mediated T-cell co-stimulation with CTLA-4-Ig (abatacept), has been recently reported to reduce relapse rate in patients with GCA in a randomized controlled trial [24]. Therefore, the results from clinical trials with targeted therapies, in addition to expanding the currently reduced therapeutic armamentarium in GCA, provide some proof of concept about the potentially involved immunopathogenic pathways (summarized in Figure 4).

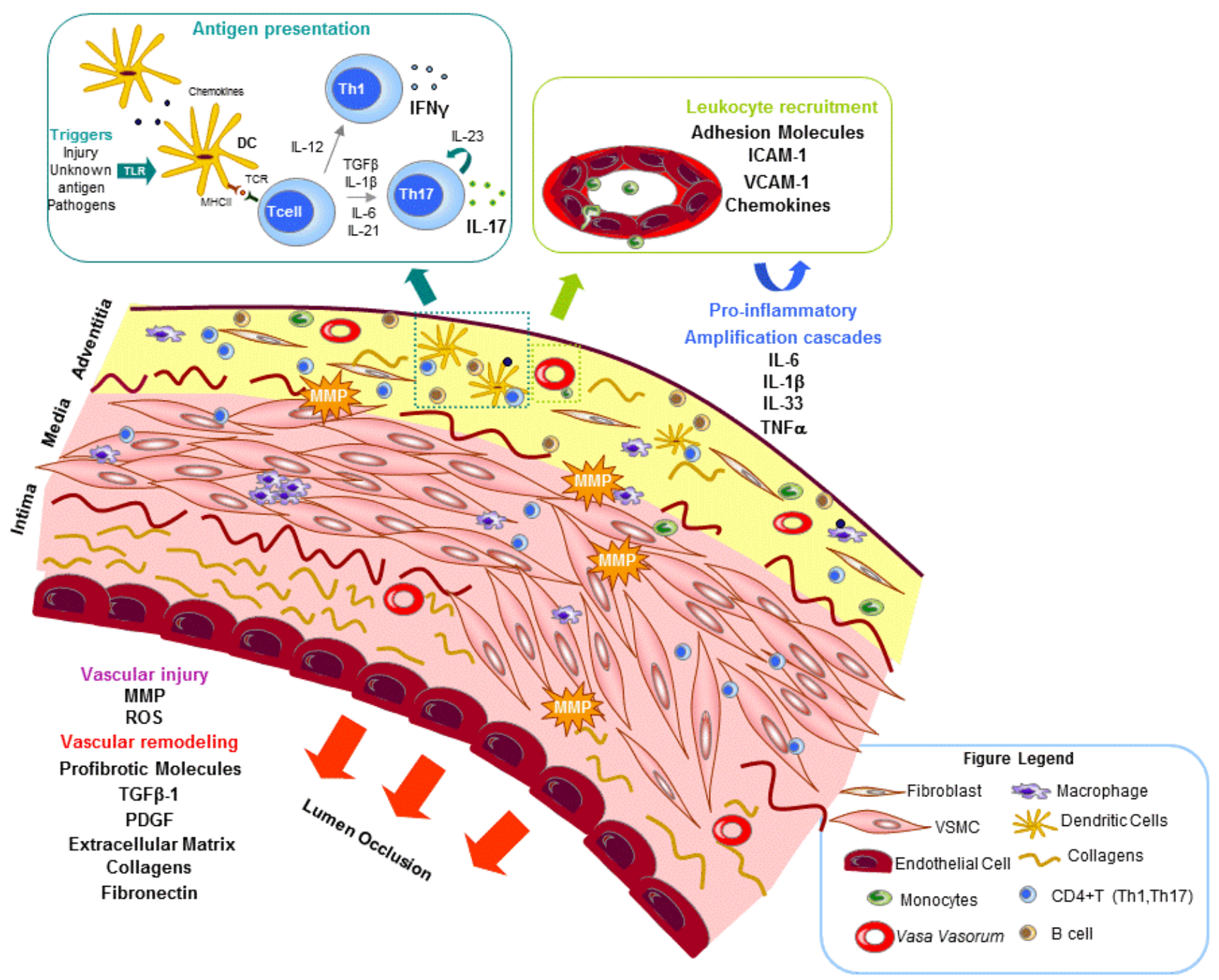

Figure 4: Summary representation of immunopathogenic mechanisms involved in vascular inflammation and remodelling in giant-cell arteritis.

\section{Vascular remodelling and occlusion}

Growth factors produced by activated macrophages or by injured vascular smooth muscle cells trigger a vascular remodelling process leading to myofibroblast differentiation of vascular smooth muscle cells, migration towards the intimal layer and deposition of extracellular matrix proteins (Figures 4 and 5). This results in intimal hyperplasia and vessel occlusion, source of symptoms of vascular insufficiency and ischemic complications in patients with GCA. Several factors including PDGFs, TGF $\beta$ and endothelin-1, able to induce myofibroblast activation and production of matrix proteins, are expressed in lesions and might participate in vascular remodelling in GCA [25,71-73]. Blocking PDGF receptor signalling with imatinib mesylate results in reduced myointimal cell outgrowth from cultured temporal arteries from patients with GCA, supporting PDGF contribution to intimal hyperplasia [52]. Increased circulating concentrations of endothelin-1 can be detected in patients with neuroophthalmic ischemic complications pointing out a potential role in vasospasm or vascular occlusion [72]. Recently, neurotrophins NGF and BDNF have been shown to be expressed in GCA lesions and promote proliferation and migration of vascular smooth muscle cells. Consequently, their participation in the generation of intimal hyperplasia has been proposed [74]. A number of micro-RNAs regulating vascular smooth muscle cell functions are up-regulated in GCA lesions further supporting their involvement in the generation of intimal hyperplasia [75]. The expression of many of the above mentioned vascular remodelling factors in lesions is not downregulated by glucocorticoids, suggesting that modulation of their 
Citation: Planas-Rigol E, Corbera-Bellalta M, Espígol-Frigolé G, Terrades-Garcia N, Alba MA, et al. (2016) Giant-Cell Arteritis: Immunopathogenic Mechanisms Involved in Vascular Inflammation and Remodeling. J Vasc 1: 103. doi:10.4172/2471-9544.100103

Page 5 of 7

potential impact in vessel stenosis and occlusion may require a specific approach in large-vessel vasculitis [26,33].

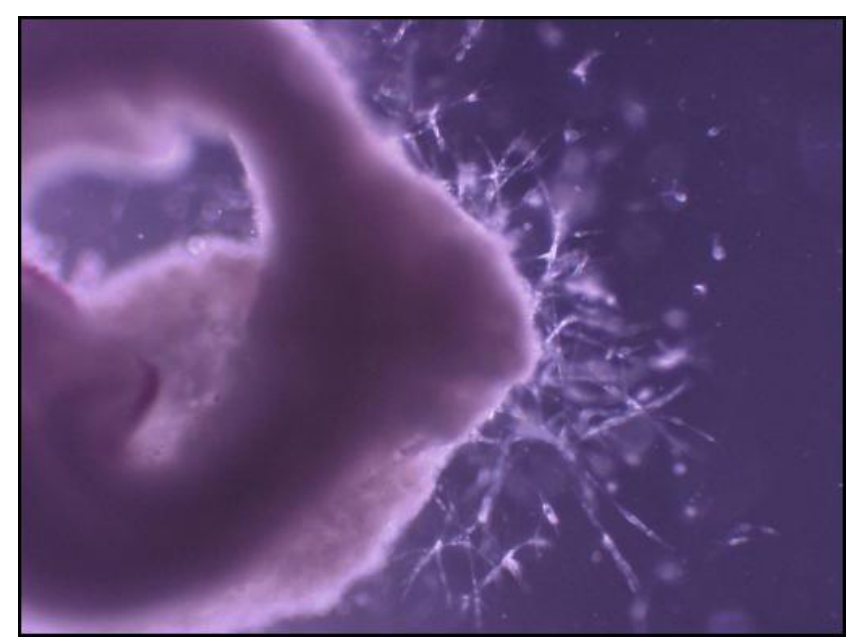

Figure 5: PDGF and other growth factors regulate myointimal cell outgrowth from temporal arteries from patients with GCA cultured on tri-dimensional matrix as in reference 52 . This may be a useful model to explore mechanisms of vascular remodelling in GCA.

\section{Acknowledgement}

Supported by Ministerio de Economía y Competitividad (SAF 2014/57708-R), Marató-TV3 2014 (201507), Instituto de Salud Carlos III (PIE13/00033) and Fondo Europeo de Desarrollo Regional (FEDER).

\section{REFERENCES}

1. Salvarani C, Pipitone N, Versari A, Hunder GG (2012) Clinical features of polymyalgia rheumatica and giant cell arteritis. Nat Rev Rheumatol 8: 509-521.

2. Hernández-Rodríguez J, Murgia G, Villar I (2016) Description and validation of histological patterns and proposal of a dynamic model of inflammatory infiltration in giant-cell arteritis. Medicine (Baltimore).

3. Cid MC, Font C, Coll-Vinent B, Grau JM (1998) Large vessel vasculitides. Curr Opin Rheumatol 10: 18-28.

4. Weyand CM, Goronzy JJ (2013) Immune mechanisms in medium and large-vessel vasculitis. Nat Rev Rheumatol 9: 731-740.

5. Gonzalez-Gay MA, Martinez-Dubois C, Agudo M, Pompei O, Blanco R, et al. (2010) Giant cell arteritis: epidemiology, diagnosis, and management. Curr Rheumatol Rep 12: 436-442.

6. Dejaco C, Duftner C, Al-Massad J, Wagner AD, Park JK, et al. (2013) NKG2D stimulated T-cell autoreactivity in giant cell arteritis and polymyalgia rheumatica. Ann Rheum Dis 72: 1852-1859.

7. Liozon E, Ouattara B, Rhaiem K, Ly K, Bezanahary H, et al. (2009) Familial aggregation in giant cell arteritis and polymyalgia rheumatica: a comprehensive literature review including 4 new families. Clin Exp Rheumatol 27: S89-94.

8. Carmona FD, González-Gay MA, Martín J (2014) Genetic component of giant cell arteritis. Rheumatology (Oxford) 53: 6-18.

9. Serrano A, Márquez A, Mackie SL, Carmona FD, Solans R (2013) Identification of the PTPN22 functional variant R620W as susceptibility genetic factor for giant cell arteritis. Ann Rheum Dis 72: 1882-1886.

10. Enjuanes A, Benavente Y, Hernández-Rodríguez J, Queralt C, Yagüe J, et al. (2012) Association of NOS2 and potential effect of VEGF, IL6, CCL2 and IL1RN polymorphisms and haplotypes on susceptibility to GCA. A simultaneous study of 130 potentially functional SNPs in 14 candidate genes. Rheumatology (Oxford) 51: 841-51.

11. Cid MC, Ercilla G, Vilaseca J, Sanmarti R, Villalta J, et al. (1988) Polymyalgia rheumatica: a syndrome associated with HLA-DR4 antigen. Arthritis Rheum 31: 678-682.

12. Carmona FD, Mackie SL, Martín JE, Taylor JC, Vaglio A, et al. (2015) A large-scale genetic analysis reveals a strong contribution of the HLA class II region to giant cell arteritis susceptibility. Am J Hum Genet 96: 565-580.

13. van Timmeren MM, Heeringa P, Kallenberg CG (2014) Infectious triggers for vasculitis. Curr Opin Rheumatol 26: 416-423.

14. Nagel MA, White T, Khmeleva N, Rempel A, Boyer PJ, et al. (2015) Analysis of Varicella-Zoster Virus in Temporal Arteries Biopsy Positive and Negative for Giant Cell Arteritis. JAMA Neurol 72: 1281-1287.

15. Bhatt AS, Manzo VE, Pedamallu CS, Duke F, Cai D, et al. (2014) In search of a candidate pathogen for giant cell arteritis: sequencing-based characterization of the giant cell arteritis microbiome. Arthritis Rheumatol 66: 1939-1944.

16. Cid MC, Campo E, Ercilla G, Palacin A, VilasecaJ, et al. (1989) Immunohistochemical analysis of lymphoid and macrophage cell subsets and their immunologic activation markers in temporal arteritis. Influence of corticosteroid treatment. Arthritis Rheum 32: 884-893.

17. Krupa WM, Dewan M, Jeon MS, Kurtin PJ, Younge BR, et al. (2002) Trapping of misdirected dendritic cells in the granulomatous lesions of giant cell arteritis. Am J Pathol 161: 1815-1823.

18. Ma-Krupa W, Jeon MS, Spoerl S, Tedder TF, Goronzy JJ, et al. (2004) Activation of arterial wall dendritic cells and breakdown of self-tolerance in giant cell arteritis. J Exp Med 199: 173-183.

19. Cid MC, Grau JM, Casademont J, Campo E, Coll-Vinent B, et al. (1994) Immunohistochemical characterization of inflammatory cells and immunologic activation markers in muscle and nerve biopsy specimens from patients with systemic polyarteritis nodosa. Arthritis Rheum 37: 1055-1061.

20. Deng J, Ma-Krupa W, Gewirtz AT, Younge BR, Goronzy JJ, et al. (2009) Toll-like receptors 4 and 5 induce distinct types of vasculitis. Circ Res 104: 488-495.

21. Weyand CM, Schönberger J, Oppitz U, Hunder NN, Hicok KC, et al. (1994) Distinct vascular lesions in giant cell arteritis share identical T cell clonotypes. J Exp Med 179: 951-960.

22. Goldstein BL, Gedmintas L, Todd DJ (2014) Drug-associated polymyalgia rheumatica/giant cell arteritis occurring in two patients after treatment with ipilimumab, an antagonist of CTLA-4. Arthritis Rheumatol 66: 768-769.

23. Hodi FS, Lawrence D, Lezcano C, Wu X, Zhou J, et al. (2014) Bevacizumab plus ipilimumab in patients with metastatic melanoma. Cancer Immunol Res 2: 632-642.

24. Langford CA, Cuthbertson D, Ytterberg SR, Khalidi NA, Monach PA, et al. (2015) A randomized double-blind trial of abatacept and glucocorticoids for the treatment of giant cell arteritis [Abstract]. Arthritis Rheumatol 67.

25. Weyand CM, Hicok KC, Hunder GG, Goronzy JJ (1994) Tissue cytokine patterns in patients with polymyalgia rheumatica and giant cell arteritis. Ann Intern Med 121: 484-491.

26. Corbera-Bellalta M, García-Martínez A, Lozano E, Planas-Rigol E, Tavera-Bahillo I, et al. (2014) Changes in biomarkers after therapeutic intervention in temporal arteries cultured in Matrigel: a new model for preclinical studies in giant-cell arteritis. Ann Rheum Dis. 73: 616-623.

27. Cid MC, Cebrián M, Font $\mathrm{C}$, Coll-Vinent $\mathrm{B}$, Hernández-Rodríguez J, et al. (2000) Cell adhesion molecules in the development of inflammatory infiltrates in giant cell arteritis: inflammation-induced angiogenesis as the preferential site of leukocyte-endothelial cell interactions. Arthritis Rheum 43: 184-194.

28. Weyand CM, Wagner AD, Björnsson J, Goronzy JJ (1996) Correlation of the topographical arrangement and the functional pattern of tissueinfiltrating macrophages in giant cell arteritis. J Clin Invest 98: 1642-1649. 
29. Cid MC, Hoffman MP, Hernández-Rodríguez J, Segarra M, Elkin M, et al. (2006) Association between increased CCL2 (MCP-1) expression in lesions and persistence of disease activity in giant-cell arteritis. Rheumatology (Oxford) 45: 1356-1363.

30. Corbera-Bellalta M, Planas-Rigol E, Lozano E, Terrades-García N, Alba MA, et al. (2015) Blocking interferon $\gamma$ reduces expression of chemokines CXCL9, CXCL10 and CXCL11 and decreases macrophage infiltration in ex vivo cultured arteries from patients with giant cell arteritis. Ann Rhem Dis. 10.1136/annrheumdis-2015-208371.

31. Espígol G, Lozano E, García-Martínez A (2007) IL-12p35, IL-12/23p40, and IL23p19 subunit expresión in giant-cell arteritis [Abstract]. Ann Rheum Dis 66: 140-141.

32. Espígol-Frigolé G, Corbera-Bellalta M, Planas-Rigol E, Lozano E, Segarra $\mathrm{M}$, et al. (2013) Increased IL-17A expression in temporal artery lesions is a predictor of sustained response to glucocorticoid treatment in patients with giant-cell arteritis. Ann Rheum Dis 72: 1481-1487.

33. Visvanathan S, Rahman MU, Hoffman GS, Xu S, García-Martínez A, et al. (2011) Tissue and serum markers of inflammation during the follow-up of patients with giant-cell arteritis--a prospective longitudinal study. Rheumatology (Oxford) 50: 2061-2070.

34. Samson M, Audia S, Fraszczak J, Trad M, Ornetti P, et al. (2012) Th1 and Th17 lymphocytes expressing CD161 are implicated in giant cell arteritis and polymyalgia rheumatica pathogenesis. Arthritis Rheum 64: 3788-3798.

35. Hernández-Rodríguez J, Segarra M, Vilardell C, Sánchez M, GarcíaMartínez A, et al. (2004) Tissue production of pro-inflammatory cytokines (IL-1beta, TNF alpha and IL-6) correlates with the intensity of the systemic inflammatory response and with corticosteroid requirements in giant-cell arteritis. Rheumatology (Oxford) 43: 294-301.

36. Terrier B, Geri G, Chaara W, Allenbach Y, Rosenzwajg M, et al. (2012) Interleukin-21 modulates Th1 and Th17 responses in giant cell arteritis. Arthritis Rheum 64: 2001-2011.

37. Miossec P1, Kolls JK (2012) Targeting IL-17 and TH17 cells in chronic inflammation. Nat Rev Drug Discov 11: 763-776.

38. Deng J, Younge BR, Olshen RA, Goronzy JJ, Weyand CM (2010) Th17 and Th1 T-cell responses in giant cell arteritis. Circulation 121: 906-915.

39. Coit P, De Lott LB, Nan B, Elner VM, Sawalha AH (2015) DNA methylation analysis of the temporal artery microenvironment in giant cell arteritis. Ann Rheum Dis. 10.1136/annrheumdis-2014-207116.

40. van der Geest KS, Abdulahad WH, Chalan P, Rutgers A, Horst G, et al. (2014) Disturbed B cell homeostasis in newly diagnosed giant cell arteritis and polymyalgia rheumatica. Arthritis Rheumatol 66: 1927-1938.

41. Alba MA, Prieto-González S, Hernández-Rodríguez J, Cid MC (2012) B lymphocytes may play a significant role in large-vessel vasculitis. Int J Clin Rheumatol 7: 475-477.

42. Bhatia A, Ell PJ, Edwards JC (2005) Anti-CD20 monoclonal antibody (rituximab) as an adjunct in the treatment of giant cell arteritis. Ann Rheum Dis 64: 1099-1100.

43. Alba MA, Espígol-Frigolé G, Butjosa M (2011) Treatment of large-vessel vasculitis. Curr Immunol Rev. 7: 435-442.

44. Baerlecken NT, Linnemann A, Gross WL, Moosig F, Vazquez-Rodriguez TR, et al. (2012) Association of ferritin autoantibodies with giant cell arteritis/polymyalgia rheumatica. Ann Rheum Dis 71: 943-947.

45. Régent A, Dib H, Ly KH, Agard C, Tamby MC, et al. (2011) Identification of target antigens of anti-endothelial cell and anti-vascular smooth muscle cell antibodies in patients with giant cell arteritis: a proteomic approach. Arthritis Res Ther 13: R107.

46. Chakravarti R, Gupta K, Swain M, Willard B, Scholtz J, et al. (2015) 14-3-3 in Thoracic Aortic Aneurysms: Identification of a Novel Autoantigen in Large Vessel Vasculitis. Arthritis Rheumatol 67: 1913-1921.

47. Esteban MJ, Font C, Hernández-Rodríguez J, Valls-Solé J, Sanmartí R, et al. (2001) Small-vessel vasculitis surrounding a spared temporal artery: clinical and pathological findings in a series of twenty-eight patients. Arthritis Rheum 44: 1387-1395.
48. Foell D, Hernández-Rodríguez J, Sánchez M, Vogl T, Cid MC, et al. (2004) Early recruitment of phagocytes contributes to the vascular inflammation of giant cell arteritis. J Pathol 204: 311-316.

49. Nadkarni S, Dalli J, Hollywood J, Mason JC, Dasgupta B, et al. (2014) Investigational analysis reveals a potential role for neutrophils in giantcell arteritis disease progression. Circ Res 114: 242-248.

50. Ciccia F, Alessandro R, Rizzo A, Raimondo S, Giardina A, et al. (2013) IL-33 is overexpressed in the inflamed arteries of patients with giant cell arteritis. Ann Rheum Dis 72: 258-264.

51. García-Martínez A, Hernández-Rodríguez J, Espígol-Frigolé G, PrietoGonzález S, Butjosa M, et al. (2010) Clinical relevance of persistently elevated circulating cytokines (tumor necrosis factor alpha and interleukin-6) in the long-term followup of patients with giant cell arteritis. Arthritis Care Res 62: 835-841.

52. Kaiser M, Younge B, Björnsson J, Goronzy JJ, Weyand CM (1999) Formation of new vasa vasorum in vasculitis. Production of angiogenic cytokines by multinucleated giant cells. Am J Pathol 155: 765-774.

53. Lozano E, Segarra M, García-Martínez A, Hernández-Rodríguez J, Cid MC (2008) Imatinib mesylate inhibits in vitro and ex vivo biological responses related to vascular occlusion in giant cell arteritis. Ann Rheum Dis 67: 1581-1588.

54. O'Neill L, Rooney P, Molloy D, Connolly M, McCormick J, et al. (2015) Regulation of Inflammation and Angiogenesis in Giant Cell Arteritis by Acute-Phase Serum Amyloid A. Arthritis Rheumatol 67: 2447-2456.

55. Cid MC, Grant DS, Hoffman GS, Auerbach R, Fauci AS, et al. (1993) Identification of haptoglobin as an angiogenic factor in sera from patients with systemic vasculitis. J Clin Invest 91: 977-985.

56. Cid MC, Hernández-Rodríguez J, Esteban MJ, Cebrián M, Gho YS, et al. (2002) Tissue and serum angiogenic activity is associated with low prevalence of ischemic complications in patients with giant-cell arteritis. Circulation 106: 1664-1671.

57. Hernández-Rodríguez J, Segarra M, Vilardell C, Sánchez M, GarcíaMartínez A, et al. (2003) Elevated production of interleukin-6 is associated with a lower incidence of disease-related ischemic events in patients with giant-cell arteritis: angiogenic activity of interleukin- 6 as a potential protective mechanism. Circulation 107: 2428-2434.

58. Segarra M, García-Martínez A, Sánchez M, Hernández-Rodríguez J, Lozano E, et al. (2007) Gelatinase expression and proteolytic activity in giant-cell arteritis. Ann Rheum Dis 66: 1429-1435.

59. García-Martínez A, Hernández-Rodríguez J, Arguis P, Paredes P, Segarra $\mathrm{M}$, et al. (2008) Development of aortic aneurysm/dilatation during the followup of patients with giant cell arteritis: a cross-sectional screening of fifty-four prospectively followed patients. Arthritis Rheum 59: 422-430.

60. Kermani TA, Warrington KJ, Crowson CS, Ytterberg SR, Hunder GG, et al. (2013) Large-vessel involvement in giant cell arteritis: a populationbased cohort study of the incidence-trends and prognosis. Ann Rheum Dis 72: 1989-1994.

61. García-Martínez A, Arguis P, Prieto-González S, Espígol-Frigolé G, Alba MA, et al. (2014) Prospective long term follow-up of a cohort of patients with giant cell arteritis screened for aortic structural damage (aneurysm or dilatation). Ann Rheum Dis 73: 1826-1832.

62. Robson JC, Kiran A, Maskell J, Hutchings A, Arden N, et al. (2015) The relative risk of aortic aneurysm in patients with giant cell arteritis compared with the general population of the UK. Ann Rheum Dis 74: 129-135.

63. Alba MA, García-Martínez A, Prieto-González S, Tavera-Bahillo I, Corbera-Bellalta M, et al. (2014) Relapses in patients with giant cell arteritis: prevalence, characteristics, and associated clinical findings in a longitudinally followed cohort of 106 patients. Medicine (Baltimore) 93: 194-201.

64. Hoffman GS, Cid MC, Rendt-Zagar KE, Merkel PA, Weyand CM, et al. (2007) Infliximab for maintenance of glucocorticosteroid-induced remission of giant cell arteritis: a randomized trial. Ann Intern Med 146: 621-630.

65. Martínez-Taboada VM, Rodríguez-Valverde V, Carreño L, López-Longo J, Figueroa M, et al. (2008) A double-blind placebo controlled trial of 
Citation: Planas-Rigol E, Corbera-Bellalta M, Espígol-Frigolé G, Terrades-Garcia N, Alba MA, et al. (2016) Giant-Cell Arteritis: Immunopathogenic Mechanisms Involved in Vascular Inflammation and Remodeling. J Vasc 1: 103. doi:10.4172/2471-9544.100103

Page 7 of 7

etanercept in patients with giant cell arteritis and corticosteroid side effects. Ann Rheum Dis 67: 625-630.

66. Seror R, Baron G, Hachulla E, Debandt M, Larroche C, et al. (2014) Adalimumab for steroid sparing in patients with giant-cell arteritis: results of a multicentre randomised controlled trial. Ann Rheum Dis 73: 2074-2081.

67. Unizony SH, Dasgupta B, Fisheleva E, Rowell L, Schett G, et al. (2013) Design of the tocilizumab in giant cell arteritis trial. Int $\mathrm{J}$ Rheumatol 2013: 912562.

68. Adler S, Reichenbach S, Kuchen S, Wermelinger F, Danet D, et al. (2015) Tocilizumab for the treatment of giant cell arteritis - a randomized placebo-controlled trial [Abstract]. Arthritis Rheumatol 67.

69. Nicklin MJ, Hughes DE, Barton JL, Ure JM, Duff GW (2000) Arterial inflammation in mice lacking the interleukin 1 receptor antagonist gene. J Exp Med 191: 303-312.

70. Chen Q, Yang W, Gupta S, Biswas P, Smith P, et al. (2008) IRF-4-binding protein inhibits interleukin-17 and interleukin-21 production by controlling the activity of IRF-4 transcription factor. Immunity 29: 899-911.
71. Kaiser M, Weyand CM, Björnsson J, Goronzy JJ (1998) Platelet-derived growth factor, intimal hyperplasia, and ischemic complications in giant cell arteritis. Arthritis Rheum 41: 623-633.

72. Lozano E, Segarra M, Corbera-Bellalta M, García-Martínez A, EspígolFrigolé G, et al. (2010) Increased expression of the endothelin system in arterial lesions from patients with giant-cell arteritis: association between elevated plasma endothelin levels and the development of ischaemic events. Ann Rheum Dis. 69: 434-442.

73. Planas-Rigol E, Corbera-Bellalta M, Alba MA, Tabera-Bahillo MA, Prieto-Gonzalez I, et al. (2012) Endothelin-1 (ET-1) induces extracellular matrix protein production by human temporal artery derived myointimal cells. a mechanism potentially leading to intimal hyperplasia and vascular occlusion in giant-cell arteritis[Abstract]. Arthritis Rheum 64: S375.

74. Ly KH, Régent A, Molina E, Saada S, Sindou P, et al. (2014) Neurotrophins are expressed in giant cell arteritis lesions and may contribute to vascular remodeling. Arthritis Res Ther 16: 487.

75. Croci S, Zerbini A, Boiardi L, Muratore F, Bisagni A, et al. (2015) MicroRNA markers of inflammation and remodelling in temporal arteries from patients with giant cell arteritis. Ann Rheum Dis. 